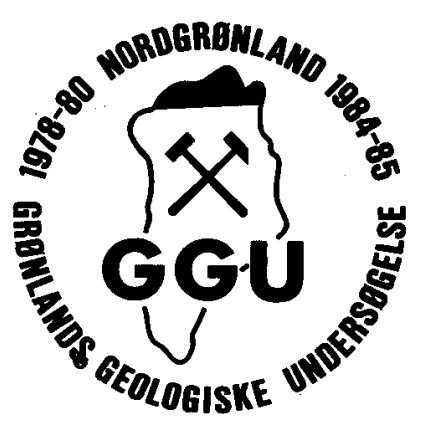

\title{
Lithostratigraphy and structure of the North Greenland fold belt in Nansen Land
}

\author{
H.-J. Bengaard, N. C. Davis, J. D. \\ Friderichsen and A. K. Higgins
}

\begin{abstract}
Field work in Nansen Land and adjacent areas in 1985 has largely confirmed the provisional lithostratigraphy of the Paradisfjeld Group and Polkorridoren Group previously established; both are Lower Cambrian deep-water sequences. Some units of the Polkorridoren Group show marked thickness variations. Two major phases of Ellesmerian (Devonian-Carboniferous) deformation are recognised, whereas Eurekan (CretaceousTertiary) events are limited to relatively minor structures, and several phases of dyke intrusion.
\end{abstract}

H.J. B., J. D. F. \& A. K. H., Grønlands Geologiske Undersøgelse, Øster Voldgade 10, DK-1350 Copenhagen K, Denmark.

N. C. D., Department of Geology, University of Sheffield, Mappin Street, Sheffield S1 3JD, U. K.

The North Greenland fold belt developed during the mid-Palaeozoic (Ellesmerian) orogeny on the site of the deep-water part of the Lower Palaeozoic Franklinian basin, which extended across North Greenland and northern Ellesmere Island. Deformation intensity and metamorphic grade increase northwards across the fold belt in North Greenland; the major folds trend E-W to ENE-WSW and in the north are overturned northwards.

Descriptions of eastern parts of the North Greenland fold belt mapped in 1979 and 1980 were given by Soper et al. (1980) and Higgins et al. (1981). In 1984 mapping was extended to the eastern part of Nansen Land (Friderichsen \& Bengaard, 1985) and in 1985 to the remainder of Nansen Land and the islands to the west (fig. 1); this report is largely concerned with observations on lithostratigraphy and structure made during 1985.

\section{Stratigraphy}

Of the six groups recognised in the Lower Palaeozoic deep-water basin sequence (Friderichsen et al., 1982), two Lower Cambrian groups are recognised in the Nansen Land region: the Paradisfjeld Group and the Polkorridoren Group (fig. 1). The Paradisfjeld Group is largely confined to the central Nansen Land anticlinorium (Friderichsen \& Bengaard, 1985), while the Polkorridoren Group occupies the surrounding areas, and extends westwards across Sverdrup $\varnothing$, Elison $\emptyset$, John Murray $\emptyset$ and Beaumont $\emptyset$. 


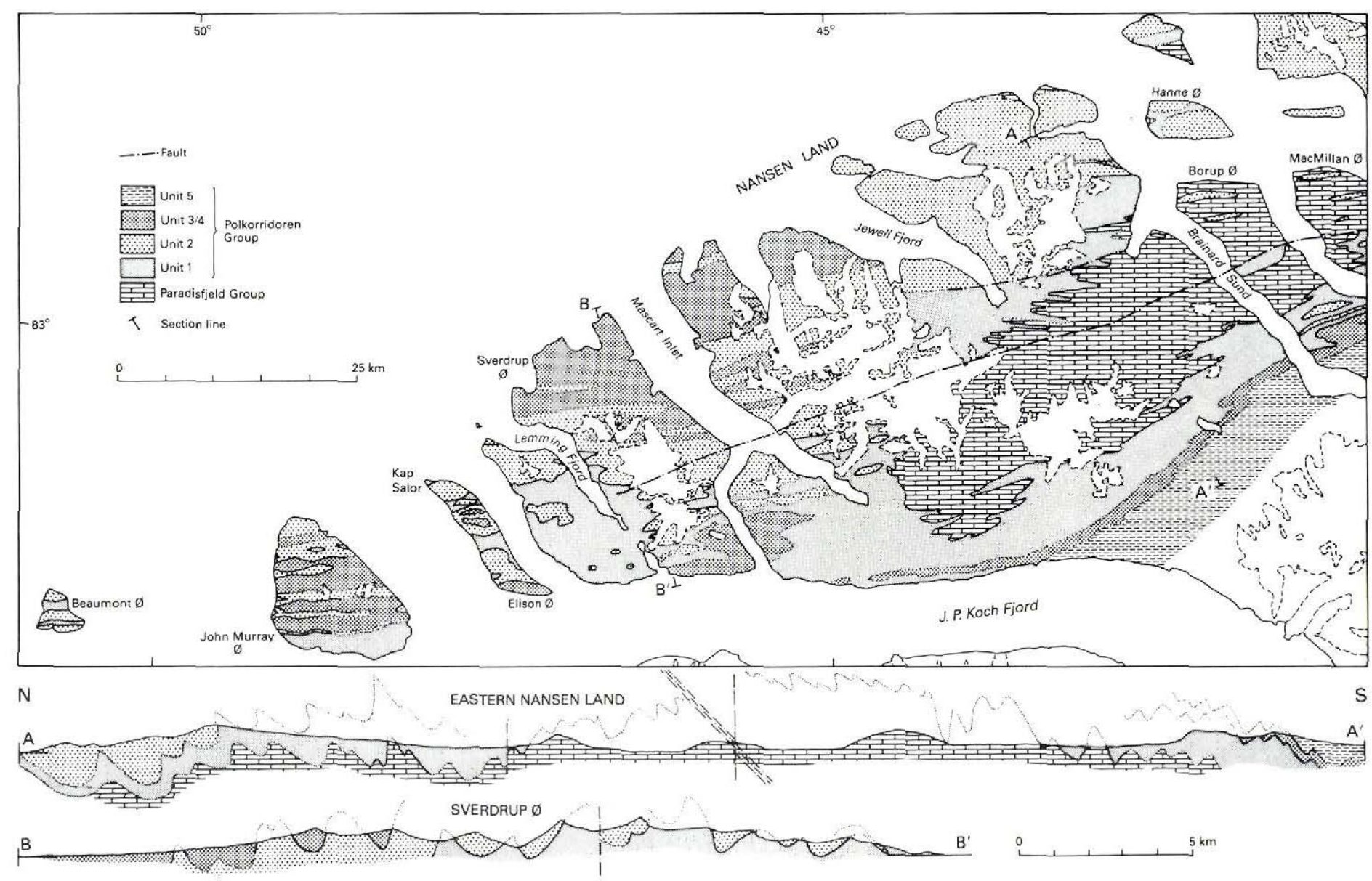

Fig. 1. Geological map of Nansen Land and adjacent islands showing lithostratigraphical units of the deep-water Paradisfjeld Group and Polkorridoren Group. Dyke swarms are not shown. The two cross-sections are from eastern Nansen Land and Sverdrup $\emptyset$, and show the style of northerly overturned F1 folds and thickness variations within Polkorridoren Group units. 


\section{Paradisfjeld Group}

As previously observed the Paradisfjeld Group can be divided into a dark weathering lower part and a light weathering upper part.

The lower part of the sequence comprises at least $1000 \mathrm{~m}$ of dark weathering rubbly limestones and orange weathering beds of thin-bedded turbiditic carbonates. Intraformational limestone conglomerates were found frequently in this sequence. This dark weathering sequence dominates the Paradisfjeld Group, of which the base is not seen in Nansen Land.

The upper, light coloured part of the Paradisfjeld Group is made up of white to bright orange coloured rocks, easily traceable in the field and on aerial photographs; it varies from 10 $\mathrm{m}$ to $200 \mathrm{~m}$ in thickness. The main rock types include massive white dolomites up to $50 \mathrm{~m}$ thick with scattered dolomite clasts, together with carbonate breccia or conglomerate beds, lime siltstones and lime mudstones. The conglomerates and breccias occur mainly towards the top of the sequence in beds from $50 \mathrm{~cm}$ to $6 \mathrm{~m}$ thick; these beds have sharp erosive bases and planar tops gradational with the overlying sediments, while clasts are often platy or tabular and up to $65 \mathrm{~cm}$ in length. Most clasts are intraformational, but scattered exotic clasts also occur. The yellow to orange-brown lime siltstones occur in beds from 5 to $60 \mathrm{~cm}$ thick, which in Nansen Land may show slumping; a few flutes and grooves in one well preserved sequence indicate a northward transport direction. Grading and the presence of flute casts suggests turbidity currents as the most probable flow mechanism.

\section{Polkorridoren Group}

The rocks of the Polkorridoren Group are mainly siliciclastic in contrast to the carbonates of the Paradisfjeld Group.

In 1984 an informal lithostratigraphy comprising five units was established for the Polkorridoren Group in eastern Nansen Land (Friderichsen \& Bengaard, 1985). In 1985 this was extended throughout Nansen Land and the islands to the west. However, two of the five units proved to be identical (units 3 and 4 , now designated unit 3/4), so that only four units remain: units $1,2,3 / 4$ and 5 .

Unit 1. Unit 1, the lowest unit of the Polkorridoren Group, is often of the order of $500 \mathrm{~m}$ thick and may exceed $1000 \mathrm{~m}$. It overlies the Paradisfjeld Group conformably in Nansen Land, and farther west, where the base is not seen, outcrops as a distinctive, dark or rusty coloured recessive sequence in anticlinal fold cores. Three sub-units are often recognised.

Much of the lowest observed part of the unit comprises grey and black siltstones and shales, with occasional quartzitic sandstones. The sandstones are coarse grained, massive, graded and matrix-poor with bed thicknesses of 3 to $4 \mathrm{~m}$. They frequently contain carbonate clasts, sometimes yellow to cream in colour, which are closely comparable to the Portfjeld Formation carbonates of the shelf sequence to the south.

The sandstone beds occur in sequences of 15 to $40 \mathrm{~m}$ thickness, but occasionally reach 100 $m$ in thickness. The sequences occur in restricted areas, where they have been seen to wedge out over short distances. Hence they were possibly deposited in broad submarine channels (perhaps up to $1 \mathrm{~km}$ wide).

Carbonate-rich lithologies, interbedded with shale and siltstone, characterise a central sequence in unit 1, very variable in thickness from place to place but usually less than $50 \mathrm{~m}$. 
The most conspicuous elements are yellow or white-weathering dolomite olistoliths, up to $300 \mathrm{~m}$ in diameter, angular, and disoriented with respect to the enveloping sediments. The olistolith lithologies include oolitic, stromatolitic and laminated dolomites, and dolomite breccias; all these can be matched with lithologies of the Portfjeld Formation (the shelf equivalent of the Paradisfjeld Group). The largest olistoliths occur in two clusters in southern Nansen Land scattered over areas of $2-3 \mathrm{~km}$ and $8 \mathrm{~km}$, characteristically in association with grey quartzites; smaller dolomite boulders from a few tens of centimetres to a few metres across can be traced at the same level as far as MacMillan $\varnothing$ to the east and John Murray $\varnothing$ to the west, an E-W distance of about $125 \mathrm{~km}$.

Other lithologies in the carbonate-rich sequence include carbonate-cemented quartzose turbidites, and dark coloured carbonate shales often with pebble-sized fragments of dolomite.

The upper part of unit 1 comprises siltstones, often with a rusty red weathering colour in northern outcrops, together with occasional channels of sandstone and sandstone turbidites. On John Murray $\varnothing$ this sequence is $200 \mathrm{~m}$ thick, while on the east side of Lemming Fjord the same sequence measures $40 \mathrm{~m}$.

The quartzitic sandstones of unit 1 may be interpreted as channel deposits from comparatively small submarine fans. The finer-grained parts of unit 1 may represent slope and baseof-slope deposits, as well as inter-channel deposits from the submarine fans. Limited palaeocurrent data show transport directions ranging from northward to westward. The angular boulders of shelf carbonate material may have been derived from fault scarps or canyons incised into the shelf margin or upper slope.

Unit 2 . Unit 2 is dominated by massive, graded sandstones, notably rich in feldspar (fig. 2), and with high matrix content. The unit reaches a thickness of $700-1000 \mathrm{~m}$ in north-west Nansen Land, Sverdrup $\emptyset$ and Beaumont $\emptyset$, where it forms high E-W trending prominent ridges; in south-west Nansen Land, south Sverdrup $\emptyset$ and John Murray $\emptyset$, unit 2 is seen to thin rapidly southwards and interfinger and wedge out in the upper part of unit 1 . Along the northern coasts of Nansen Land and Sverdrup $\varnothing$, unit 2 is overlain by the predominantly finer-grained lithologies of unit 3/4.

Around Mascart Inlet the unit 2 sequence is divided into two sandstone divisions, each about $250 \mathrm{~m}$ thick, by $200 \mathrm{~m}$ of mudstone and thin-bedded sandstone. The lower division comprises massive turbidite beds, up to $15 \mathrm{~m}$ thick, of which the lower 1-3 m may be mudflake conglomerate. Towards the north the thick mudstone unit interdigitates with the two sandstone divisions and can no longer be traced.

Rapid thickness variations have been recorded in laterally equivalent sandstone sequences on Elison $\varnothing$, John Murray $\emptyset$ and Beaumont $\emptyset$. A lower sandstone sequence in three measured sections on Beaumont $\emptyset$ was logged at $255 \mathrm{~m}, 170 \mathrm{~m}$ and $490 \mathrm{~m}$, and an overlying mudstone at $30 \mathrm{~m}, 46 \mathrm{~m}$ and $114 \mathrm{~m}$. Substantial parts of these sequences are formed by thick, coarse-grained sandstone turbidite beds up to $6 \mathrm{~m}$ thick, an exceptional $25 \mathrm{~m}$ bed being noted in northern Beaumont $\emptyset$; these thick beds commonly have scoured bases with a relief of $30 \mathrm{~cm}$, sometimes as much as $1.5 \mathrm{~m}$.

The turbidites of unit 2 are characteristically very poorly sorted texturally and mineralogically; some beds contain up to $60 \%$ feldspar grains, tabular rip-up mud clasts, and occasional orange-weathering carbonate clasts. The lower parts of beds are often of granule grain size (fig. 2). Feldspar appears to be more abundant in coarser beds. The large amounts of 


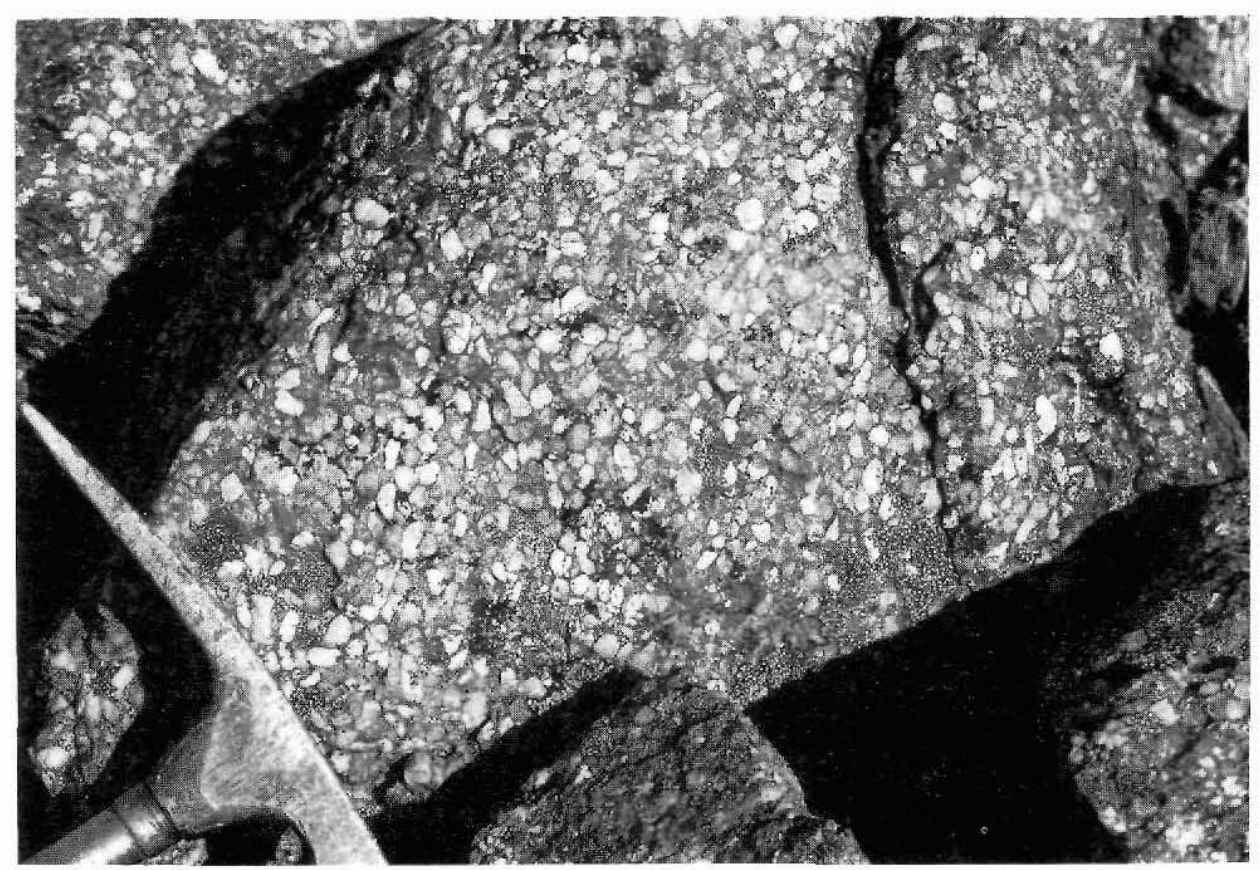

Fig. 2. Base of unit 2 sandstone turbidite bed on Beaumont $\varnothing$, showing coarse grain size (granule to fine pebble) and the high proportion of feldspar which distinguishes unit 2 sandstones from those in other units.

feldspar imply rapid weathering in the source area (unknown), and rapid transportation into the deep-water basin. There are very few palaeocurrent indicators in unit 2 , and the evidence that is found can be variously interpreted.

Unit 3/4. Unit $3 / 4$ is here used as a designation for the sequences distinguished as units 3 and 4 by Friderichsen \& Bengaard (1985). These sequences were more thoroughly investigated in 1985 and shown to be broadly equivalent. Both consist of greenish mudstones, occasionally purple mudstones, and thin-bedded sandstone turbidite sequences. In southern Nansen Land unit $3 / 4$ (formerly termed unit 4) is $200-300 \mathrm{~m}$ thick, and has transitional boundaries with unit 1 below (unit 2 is not developed) and unit 5 above. In north-west Nansen Land and northern Sverdrup $\varnothing$ the sequence (formerly termed unit 3 ) is widely exposed overlying unit 2 and is at least $600 \mathrm{~m}$ thick; the top is not seen.

Apart from the appearance of significant proportions of mudstone in the sequence, unit $3 / 4$ is characterised by a change in the nature of the sandstone turbidites compared to unit 2 ; feldspar is rare, and quartz grains are notably well rounded. In the field the turbidites were described as quartzites, and were often conspicuous because of secondary quartz veining.

Fine-grained lithologies dominate the unit $3 / 4$ sequence. The mudstones, often friable and papery, are usually greenish in colour, but may be purple, black or mauve. Siltstones show a greater range of sedimentary structures; the beds form thin streaks and drapes, or discrete beds up to $8 \mathrm{~cm}$ thick, or form sequences with thin lenses of cross-laminated, fine-grained sandstones. 


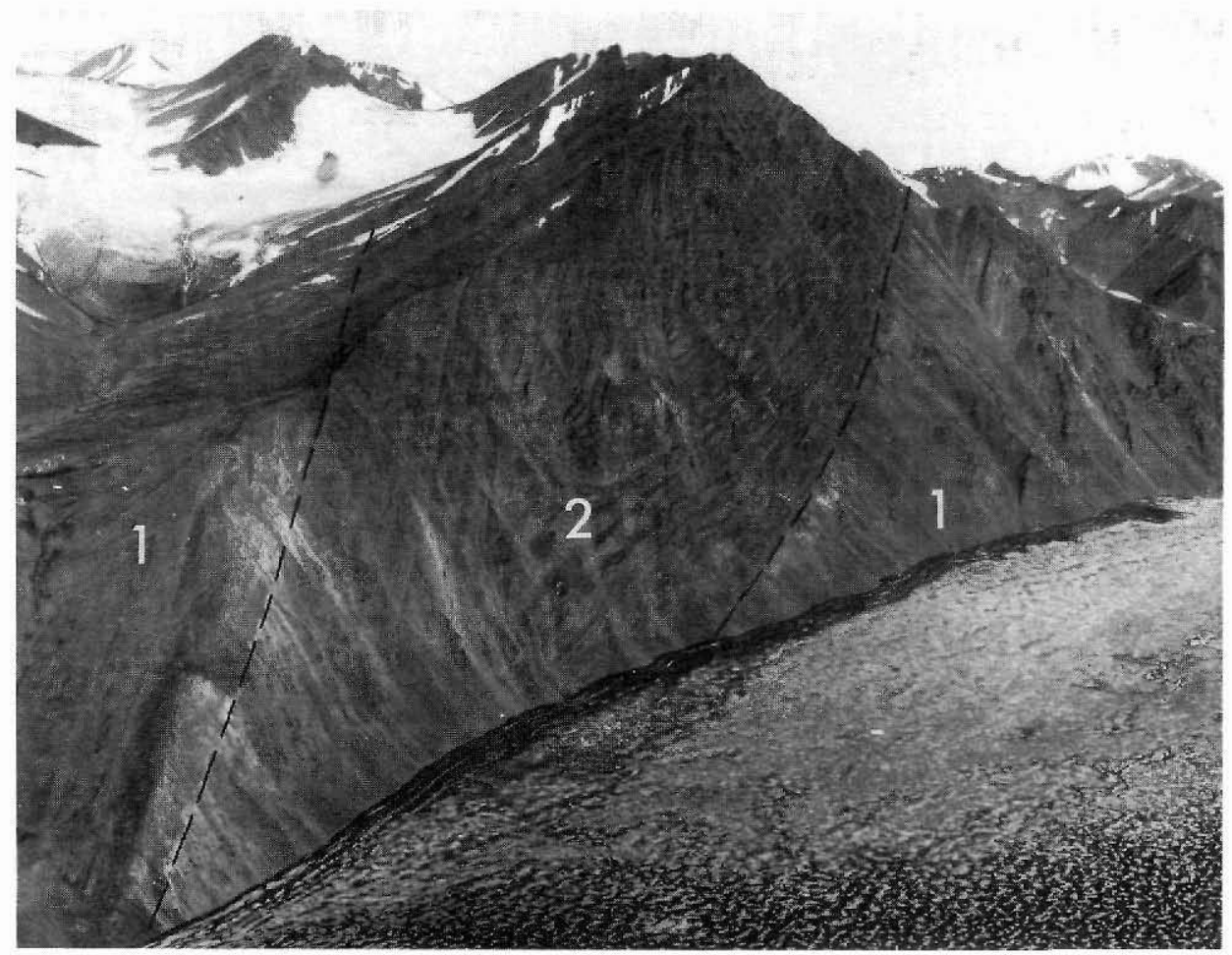

Fig. 3. Northerly overturned major fold in north-east Nansen Land, involving units 1 and 2 of the Polkorridoren Group. Highest summits reach $1100 \mathrm{~m}$.

The quartzitic turbidites occur as isolated beds up to $25 \mathrm{~cm}$ thick in the shale sequences, or as packages of thin beds totalling up to $50 \mathrm{~m}$ in thickness. The bases of beds often exhibit large flute and groove casts up to $1 \mathrm{~m}$ long and $10 \mathrm{~cm}$ deep. The upper parts of beds show current ripple cross-lamination, draped by fine sandstone and siltstone. Trace fossils are abundant in unit $3 / 4$, usually occurring on the bases of thin sandstone turbidites.

Abundant palaeocurrent indicators in unit $3 / 4$ all indicate a northerly transport direction.

Unit 5. This uppermost purple and green mudstone unit of the Polkorridoren Group is known in the Peary Land region as the Frigg Fjord mudstone (Friderichsen et al., 1982). It is found as a completely recrystallised chloritoid schist in south-east Nansen Land and southern Borup $\varnothing$ (fig. 1). The coloured mudstones of the Frigg Fjord mudstone (= unit 5) have been correlated with variegated mudstones within the Buen Formation of the shelf (Surlyk et al., 1980; Higgins \& Soper, 1985; Davis \& Higgins, 1987).

\section{Structures}

The dominant structures of the Nansen Land region are E-W trending, tight, major folds (F1) which have kilometre scale amplitudes and wavelengths. In the extreme south of Nan- 
sen Land the folds are upright, but northwards they become more overturned to the north (figs 1 \& 3). A moderate to strongly developed S1 slaty cleavage is developed in fine-grained lithologies; in psammitic rocks the cleavage is spaced, shows strong refraction and, in the north, metamorphic differentiation.

Low grade metamorphism accompanied D1 deformation. Most of the region exhibits greenschist facies assemblages. Chloritoid occurs in the fine-grained lithologies of unit 5 in south-east Nansen Land, and unit 3/4 in northern Sverdrup $\varnothing$; in northernmost Nansen Land biotite coexists with chlorite and muscovite. These assemblages indicate a slight increase in grade northwards across the region.

Shallow south-dipping S2 crenulation cleavage was encountered only sporadically in Polkorridoren Group lithologies in 1985; much of the supposed S2 cleavage reported in psammites by Friderichsen \& Bengaard (1985) was found to be strongly refracted S1 cleavage. D2 mylonitic developments reported from Paradisfjeld Group lithologies (Friderichsen \& Bengaard, 1985) were found again in 1985, associated with strongly north-verging F1 folds, and seem to support the suggestion by Soper \& Higgins (1985) that the northerly overturning of F1 folds is due to the superimposition of D2 strain. No major D2 structures other than the mylonites have been recorded in Nansen Land.

Both D1 and D2 deformation phases are of Ellesmerian (Devonian - Lower Carboniferous) age. Several later phases of minor deformation apparently related to dyke intrusion are probably Eurekan (late Cretaceous to Tertiary) in age (Friderichsen \& Bengaard, 1985).

A NNE-SSW trending steep cleavage, associated with a few folds, cuts the D2 mylonites, and is thought to be related to strike-slip displacement on the Harder Fjord fault zone. In 1985 this fault zone was traced as far as central Sverdrup $\varnothing$; displacement, thought to be about $20 \mathrm{~km}$ dextral in the east, appears to be decreasing westwards, and the continuation of the fault farther west is unclear.

A NNW-SSE steep cleavage is conspicuous in southern parts of the region, where it is axial planar to minor chevron style folds. It is more sporadically developed in the rest of the area, but in northernmost Nansen Land it was found in dykes of the oldest dyke generation as a jointing. In south-west Nansen Land major folds are locally developed on a kilometre scale and are superimposed on major F1 folds; they are responsible for irregular trends of the boundary between the Paradisfjeld Group and Polkorridoren Group in this area.

\section{Dykes}

The late Cretaceous dyke swarms (Batten et al., 1981; Soper et al., 1982) reach their greatest density in northern Nansen Land, where, over a $50 \mathrm{~km}$ broad zone, dilation due to N-S and NNW-SEE trending dykes ranges from 25-60\%. In north-west Nansen Land and Sverdrup $\varnothing$ the majority of dykes are NW-SE trending, and amount to at most $10 \%$ of the outcrops. They are considered to be younger than the N-S dykes (Friderichsen \& Bengaard, 1985), mainly because of their regional pattern, since evidence from cross-cutting intersections is scarce. The possibly youngest dykes are E-W to ENE-WSW trending and are most conspicuous in southern Nansen Land; single dykes can occasionally be traced for distances of up to $30 \mathrm{~km}$. 


\section{References}

Batten, D. J., Brown, P. E., Dawes, P. R., Higgins, A. K., Koch, B. E., Parsons, I. \& Soper, N. J. 1981: Peralkaline volcanicity on the Eurasia Basin margin. Nature, Lond. 294, 150-152.

Davis, N. C. \& Higgins, A. K. 1987: Cambrian - Lower Silurian stratigraphy in the fold and thrust zone between northern Nyeboe Land and J. P. Koch Fjord, North Greenland. Rapp. Grønlands geol. Unders. 133, 91-98.

Friderichsen, J. D. \& Bengaard, H.-J. 1985: The North Greenland fold belt in eastern Nansen Land. Rapp. Grønlands geol. Unders. 126, 69-78.

Friderichsen, J. D., Higgins, A. K., Hurst, J. M., Pedersen, S. A. S., Soper, N. J. \& Surlyk, F. 1982: Lithostratigraphic framework of the Upper Proterozoic and Lower Palaeozoic deep-water clastic deposits of North Greenland. Rapp. Grønlands geol. Unders. 107, $20 \mathrm{pp}$.

Higgins, A. K. \& Soper, N. J. 1985: Cambrian - Lower Silurian slope and basin stratigraphy between northern Nyeboe Land and western Amundsen Land, North Greenland. Rapp. Grønlands geol. Unders. 126, 79-86.

Higgins, A. K., Friderichsen, J. D. \& Soper, N. J. 1981: The North Greenland fold belt between central Johannes V. Jensen Land and eastern Nansen Land. Rapp. Grønlands geol. Unders. 106, 35-45.

Soper, N. J. \& Higgins, A. K. 1985: Thin-skinned structures at the basin-shelf transition in North Greenland. Rapp. Grønlands geol. Unders. 126, 87-94.

Soper, N. J., Higgins, A. K. \& Friderichsen, J. D. 1980: The North Greenland fold belt in eastern Johannes V. Jensen Land. Rapp. Grønlands geol. Unders. 99, 89-98.

Soper, N. J., Dawes, P. R. \& Higgins, A. K. 1982: Cretaceous-Tertiary magmatic and tectonic events in North Greenland and the history of adjacent ocean basins. In Dawes, P. R. \& Kerr, J. W. (edit.) Nares Strait and the drift of Greenland: a conflict in plate tectonics. Meddr Grønland, Geosci. 8, 205220.

Surlyk, F., Hurst, J. M. \& Bjerreskov, M. 1980: First age-diagnostic fossils from the central part of the North Greenland foldbelt. Nature, Lond. 286, 800-803. 